\title{
Pandangan Dunia Pengarang dalam Novel 1Q84 Karya Murakami
}

\section{Mohammad Rizky Afrillah*, Ely Triasih Rahayu, Dian Bayu Firmansyah, Eko Kurniawan}

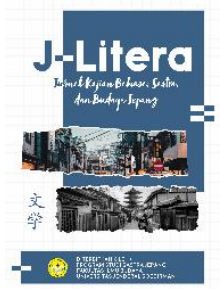

${ }^{*}$ Program Studi Sastra Jepang, Universitas Jenderal Soedirman, Purwokerto, Indonesia

\begin{abstract}
This researches disscuses author's world view in 1Q84, a novel by Haruki Murakami using Goldmann genetic structuralism analyses. The purpose of this researches is author world views in that novel. Research method being used is descriptive qualitative. Data collect method being used are "Simak catat" technique and also library research technique. The result of this research shown that Murakami's world views that he expressed in this novel is negative views about religious people.
\end{abstract}

Keywords:

Genetic structuralism; author's world views; 1Q84; Haruki Murakami; Japanese Religion.

Article Info:

First received:

14 November 2019

Available online:

30 November 2019

\section{INTRODUCTION}

Definisi mengenai sastra cukup beragam karena masing-masing tokoh mempunyai pandangan mengenai definisi sastra itu sendiri. Sastra dapat disebut suatu karya seni manusia yang tentunya dapat dinikmati oleh penikmatnya. Seperti karya seni pada umumnya, karya sastra pun memiliki nilai estetik tersendiri bagi penikmatnya. Menurut Rene Wellek dan Austrin Warren (Wellek dan Warren 1989: 3-4), sastra adalah suatu kegiatan kreatif, sebuah karya seni.

Sastra pun menarik ilmu sosiologi sebagai salah satu kajiannya. Swingewood mendefinisikan sosiologi sebagai studi yang ilmiah dan objektif mengenai manusia dalam masyarakat dan juga lembaga serta proses sosial (dalam Faruk 2012: 1).

Salah satu bentuk karya sastra yang paling mudah dinikmati oleh semua kalangan adalah novel. Pengkajian sebuah novel dalam perspektif sastra dapat dilakukan untuk memahami baik tema, maupun isu yang dituangkan oleh pengarang dalam novel tersebut. Novel menjadi karya sastra yang tetap menunjukan keeksisannya meskipun di era teknologi ini.

Salah satu contoh novel populer dalam dunia sastra modern Jepang adalah 1Q84 (baca: Ichi-Kew-Hachi-Yon) yang di tulis oleh Haruki Murakami. novel dari Murakami yang mengangkat isu masyarakat Jepang dalam hal sekte-sekte keagamaan. Jepang bukan lah negara yang religius dan membebaskan penduduknya dari status agama. Terlepas dari undang-undangnya yang longgar mengenai pengaturan agama bagigi penduduknya, Jepang memiliki banyak sekte sekte keagamaan atau disebut dengan istilah Agama baru.

Ketika pembaca novel tersebut ingin mengetahui pandangan dunia pengarang, diperlukannya teori untuk memahami hal tersebut. Salah satu cabang dalam kajian sastra terdapat satu teori yang disusun oleh Lucien Goldmann yang bernama teori strukturalisme genetik. Teori tersebut dapat digunakan untuk mengetahui pandangan dunia pengarang dari sebuah novel. Teori ini juga meyakini adanya kesamaan struktur dari pandangan dunia 
Pengarang dengan struktur masyarakat yang berlaku di mana karya sastra itu diciptakan. Teori ini digunakan agar dapat menganalisis pandangan dunia pengarang dalam sebuah novel, sehingga hasil yang diharapkan dalam penelitian ini adalah menemukan pandangan dunia pengarang dalam novel $1 Q 84$.

\section{TINJAUAN PUSTAKA}

Strukturalisme genetik adalah Teori yang dikemukakan oleh sosiolog Rumania-Prancis, Goldmann. Teori ini muncul atas dasar penolakan terhadap strukturalisme murni. Goldmann percaya bahwa karya sastra merupakan struktur. Struktur tersebut merupakan produk dari proses sejarah yang terus berlangsung, proses strukturasi dan destrukturasi yang hidup dan di hayati oleh masyarakat dari karya tersebut (dalam Faruk 2012: 56). Ratna (2006: 123) menambahkan secara definitif strukturalisme genetik adalah analisis struktur dengan memberikan perhatian terhadap asal-usul karya dengan kata lain sekaligus memberikan perhatian terhadap unsur intrinsik suatu karya sastra maupun unsur ekstrinsiknya. Sehingga dapat diambil poin penting mengenai teori strukturalisme genetik yaitu mengukuhkan adanya kesamaan struktur antara karya sastra dengan masyarakat dimana karya sastra tersebut diciptakan yang tergambar melalui pandangan dunia pengarang.

Sebagai sebuah teori, strukturalisme genetik masih terbangun oleh beberapa konsep dasar yang ikut menopang teori tersebut. Konsep-konsep dasar tersebut yaitu fakta kemanusiaan, subjek kolektif, pandangan dunia, serta pemahaman dan penjelasan. Pandangan Dunia menurut Goldmann adalah Goldmann (dalam Faruk 2012: 65-66) yaitu kompleks menyeluruh dari gagasan, aspirasi, maupun perasaan yang menghubungkan anggota-anggota dalam suatu kelompok dan mempertentangkan dengan kelompok lainnya.

Penelitian pandangan dunia tidak cukup dari sisi tekstual, atau hanya dari objek material, namun yang terpenting harus mempertimbangkan dari sisi eksternal seperti latar sosial budaya, biografi pengarang, dan lain-lain yang relevan dengan konsep pandangan dunia. Menurut Ratna (2006: 126) tidak seperti tema, amanat, dan pesan-pesan lain yang harus diteliti secara tekstual, pandangan dunia harus dicari dengan mengungkapkan pandangan kelas sosial, menelusurinya dari sisi historis dengan melibatkan ilmu multidisplin.

\section{METODE PENELITIAN}

Jenis penelitian yang akan digunakan adalah deskriptif kualitatif. Menurut Moleong (2004: 6), penelitian kualitatif adalah penelitian yang bermaksud untuk memahami fenomena tentang apa yang dialami oleh subjek penelitian misalnya perilaku, persepsi, motivasi, tindakan, dan lain-lain. Hal yang difokuskan dalam penelitian ini adalah Pandangan Dunia pengarang dalam novel 1Q84 karya Haruki Murakami menggunakan teori strukturalisme genetik.

\section{HASIL DAN PEMBAHASAN}

1Q84 (Ichi-Kew-Hachi-Yon) merupakan salah satu novel karya Haruki Murakami pada tahun 2009. 1Q84 menggunakan latar fiksi Tokyo pada tahun 1984. Novel ini memiliki cara penceritaan yang cukup berbeda dan unik jika dibandingkan dengan novel umumnya. Hal unik tersebut dibuat oleh Murakami yang cukup populer dengan novel ber-genre surealis. Gaya penceritaan dalam novel ini dibuat Murakami dengan unik, sebagai contoh bab satu akan menceritakan alur dari sudut pandang Aomame, seorang pelatih olahraga yang memiliki kegiatan sampingan sebagai Eksekutor. Bab dua akan menceritakan dari sudut pandang Tengo, seorang guru bimbel matematika yang terjebak dalam skandal dunia sastra yaitu penulisan ulang novel "Kepompong Udara" sebagai ghost writer. Bab selanjutnya kembali ke Aomame, dan bab setelahnya kembali ke Tengo.

1Q84 menjadi media bagi Murakami untuk menuangkan pandangan duniannya mengenai Issue tertentu. Salah satu yang dituangkan dalam novel ini adalah stigma negatifnya kepada para pemeluk agama. 
Pemeluk agama yang digambarkan Murakami dalam novelnya sebagai orang yang hanya mengikuti ajaran agama secara fanatik walaupun hal itu bertentangan dengan logika. Berikut adalah kutipan data yang membicarakan hal tersebut terletak pada jilid 1 bab 19 halaman 432 yaitu:

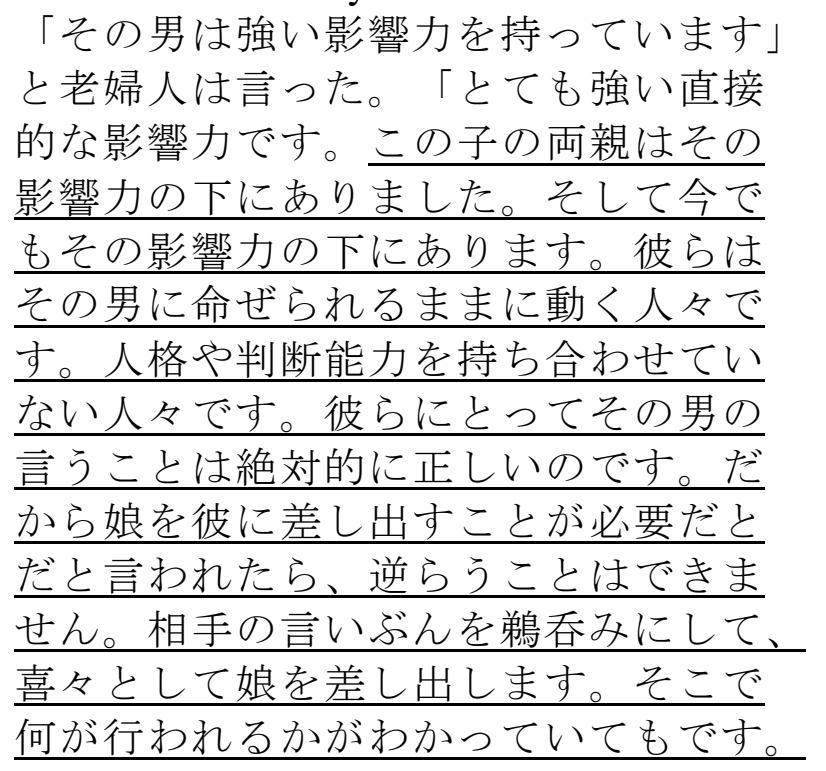

"Sono otoko wa tsuyoi eikyouryoku wo motteimasu" to roufujin wa itta. "totemo tsuyoi chokusetsuteki na eikyouryoku desu. Kono ko no ryoushin wa sono eikyouryoku no shita ni arimashita. Soshite ima demo sono eikyouryoku no shita ni arimasu. Karera wa sono otoko ni meizerareru mamani ugoku hitobito desu. Jinkyaku ya handan nouryoku wo mochi awaseteinai hitobito desu. Karera ni totte sono otoko no iu koto wa zettai teki ni tadashii no desu. Dakara musume wo kare ni sashi dasu koto ga hitsuyou da to iwaretara, sakarau koto wa dekimasen. Aite no iibun wo uno mi ni shite, kiki toshite musume wo sashidashimasu. Soko de nani ga okonawareru ka ga wakatteitemo desu.

"Laki-laki itu memiliki pengaruh yang cukup kuat," kata Wanita tua itu. "Laki-laki itu mampu mempengaruhi orang dengan sangat kuat dan secara langsung. Orangtua anak ini berada di bawah pengaruh laki-laki itu hingga saat ini. Mereka bergerak persis sesuai dengan perintahnya. Tidak punya kepribadian ataupun kemampuan untuk menilai sendiri. Bagi mereka, perkataan lakilaki itu adalah sabda yang mutlak kebenarannya. Karena itu, jika laki-laki itu mengatakan bahwa mereka harus mempersembahkan anak mereka kepadanya, mereka tidak bisa menolak. Mereka telan mentah-mentah perkataannya, lalu mempersembahkan anak mereka kepadanya dengan senang hati, meskipun mereka sudah tahu apa yang akan terjadi pada anak mereka."

(IQ84 J1 B19 H432)

Latar dari kutipan data diatas adalah dialog antara Aomame dengan Wanita Tua (Roufuujin) ketika membahas suatu tindak kriminal yang dilakukan oleh Pemimpin dari sekte Sakigake. Topik dari pembicaraan yang diangkat adalah mengenai pengikut dari sekte tersebut. Murakami menuangkan pandangannya mengenai para pemeluk agama tersebut melalui narasi-narasi dalam novelnya. Kutipan data diatas menjelaskan karakter salah satu pemeluk sekte Sakigake yaitu tidak punya kepribadian ataupun kemampuan menilai dengan logika. Hal itu dijelaskan oleh Wanita Tua dalam narasi yaitu "Orangtua anak ini berada di bawah pengaruh laki-laki itu hingga saat ini. Mereka bergerak persis sesuai dengan perintahnya. Tidak punya kepribadian ataupun kemampuan untuk menilai sendiri (Kono ko no ryoushin wa sono eikyouryoku no shita ni arimashita. Karera wa sono otoko ni meizerareru mama ni ugoku hitobito desu. Jinkyaku ya, handan nouryoku wo mochiawaseteinai hitobito)". Perkataan dari Wanita Tua tersebut yang menjadi pandangan mengenai pemeluk agama yang dituangkan Murakami dalam narasinya. Murakami melanjutkan bahwa hal tersebut berdasarkan perbuatan dari salah satu pemeluk Sakigake yang dengan rela menyerahkan anak perempuannya kepada sekte. Narasi dituangkan melalui perkataan Wanita Tua Yaitu: "Jika laki-laki itu (pemimpin sekte Sakigake) mengatakan bahwa mereka harus mempersembahkan anak mereka kepadanya, mereka tidak bisa menolak. mereka telan mentah perkataanya, lalu mempersembahkan anak mereka kepadanya dengan senang hati (Musume wo 
kare ni sashi dasu koto ga hitsuyou da to iwaretara, Aite no iibun wo uno mi ni shite, kiki toshite musume wo sashidashimasu)". Berdasarkan kutipan data diatas, Murakami menggambarkan dalam novelnya bahwa para pemeluk agama adalah orang-orang yang tidak memiliki kepribadian. Hal itu karena mereka rela melakukan ajaran agama nya tanpa menilai terlebih dahulu kelogisan dari ajaran agamanya. Murakami melalui kutipan data diatas menggambarkannya dengan orang tua anak salah satu pemeluk sekte Sakigake yang rela menyerahkan anak perempuannya kepada pemimpin sekte tersebut.

Kutipan data selanjutnya merupakan penggambaran dari Murakami mengenai sekte keagamaan. Menurut nya sekte agama merupakan tempat bagi sekumpulan orang berjiwa kerdil maupun orang-orang yang tak memiliki kemampuan untuk menilai sendiri dengan kata lain orang-orang yang tak menggunakan logika dalam agamanya. Kutipan data tersebut terletak pada jilid 1 bab 19 halaman 432-433 yaitu :

「それは何か、特殊な団体なのです か?

「そうです。狭い病んだ精神を共有 する特殊な団体です」

「カルトのようなもの?」と青豆は
尋ねた。

老婦人は肯いた。「そうです。それ もきわめて悪質で危険なカルトです」 もちろんだ。それはカルトでしかあ り得ない。命ぜられるままに動く 人々。人客や判断能力を持ち合わせ ていない人。同じことが私の身に起 こっていたとしてもおかしいくはな かったんだ、と青豆は唇を嚙みしめ ながら思った。

"sore wa nani ka, tokushu na dantai na no desuka?" "sou desu. Semai yanda seishin wo kyouyuu suru tokushu na dantai desu”"

"Karuto no youna mono" to Aomame wa tazuneta.

"Roufujin wa unazuita. "sou desu. Soremo kiwamete akushitsu de kiken na karuto desu"

"Mochironda. Sore wa karuto de shika arienai. Meizerareru mama ni ugoku hitobito. Jinkyaku ya handan nouryoku wo mochi awaseteinai hito. Onaji koto ga watashi no mi ni okotteita toshitemo okashiiku wa nakattanda, to aomame wa kuchibiru wo kamishimenagara omotta.

"Apakah itu semacam organisasi khusus?"

"Betul, Organisasi khusus untuk berbagi jiwa yang kerdil dan sakit."

“Semacam kultus (Cult)?" tanya Aomame.

Wanita tua itu mengangguk. "Betul, Kultus (Cult) yang sangat jahat dan berbahaya."

Tentu saja. Apalagi kalau bukan kultus (Cult)? Orang-orang yang bergerak persis sesuai dengan perintah. Orang-orang yang tidak memiliki kepribadian ataupun kemampuan menilai sendiri. Hal yang sama bisa terjadi pada diriku sendiri, pikir Aomame sambil menggigit bibirnya.

(1Q84 J1 B19 H432-433).

Dialog dari data diatas juga terjadi ketika Aomame berdiskusi dengan Wanita tua di tempat yang sama yaitu kediaman dari Wanita tua. Topik pembicaraan yang diangkat masih seputar sekte Sakigake. Narasi diatas menjelaskan mengenai Sakigake sebagai sekte keagamaan dan pemeluknya yang berjiwa kerdil. Hal itu berdasarkan perkataan Wanita Tua kepada Aomame yaitu "Betul, organisasi khusus untuk berbagi jiwa yang kerdil dan sakit (Sou desu. Semai yanda seishin wo kyouyuu suru tokushuu na dantai desu)". Wanita Tua menambahkan bahwa organisasi tersebut semacam kultus atau sistem 
kepercayaan berdasarkan narasi "Kultus (Cult) yang sangat jahat dan berbahaya (Soremo kiwamete akushitsu de kiken na karuto desu)". Selanjutnya Aomame menambahkan para pemeluk dari sekte keagamaan tersebut merupakan orangorang yang tidak punya kepribadian dan kemampuan berpikir logis berdasarkan narasi "Apalagi kalau bukan kultus (cult)? Orang-orang yang bergerak persis sesuai dengan perintah, orang-orang yang tidak memiliki kepribadian ataupun kemampuan menilai sendiri (Sore wa karuto de shika arienai. Meizerareru mama ni ugoku hitobito. Jinkyaku ya handan nouryoku wo mochiawaseteinai hito)". Kutipan data tersebut juga menjelaskan pandangan Murakami mengenai para pemeluk agama yang hanya mengikuti suatu ajaran agama tanpa menggunakan akal sehat dan logika mengenai ajaran tersebut. Murakami juga menambahkan organisasi sekte keagamaan atau bisa disebut sebagai kultus (Cult) adalah organisasi bagi orang-orang berjiwa kerdil dan sakit.

Berdasarkan data-data yang telah dijabarkan diatas, Pandangan yang dituangkan Murakami mengenai para pemeluk agama menunjukkan stigma yang negatif. Dua kutipan data tersebut menjelaskan tentang pemeluk agama atau sekte keagamaan yang dengan patuhnya mentaati perintah dari pemimpin agama meskipun tidak masuk akal. Murakami melalui narasi selanjutnya menyebut bahwa orang-orang kultus adalah orang yang berjiwa kerdil, tidak memiliki kepribadian dan tidak menggunakan pikirannya untuk menyanggah perintah tersebut. Stigma negatif dari Murakami kepada para pemeluk agama yang digambarkan melalui novelnya ini dapat diasumsikan berasal dari pengalamannya setelah menulis non fiksi yang berjudul Underground yang terbit pada tahun 1996.

Underground adalah sebuah esai non fiksi dari Murakami yang berisi hasil wawancara dan testimoni korban-korban teror gas sarin Tokyo yang terjadi pada 20
Maret 1995. Teror tersebut dilakukan oleh sebuah sekte agama yang bernama Aum Shinrikyou. Pada tahun 1995 sekte agama Aum Shinrikyou yang dipimpin oleh Shoko Asahara melakukan teror di stasiun kereta di Tokyo menggunakan suatu gas saraf yang disebut Sarin. Dampak dari teror tersebut cukup besar bagi masyarakat Jepang baik dari sisi fisik bagi korban yang terkena langsung seperti sesak nafas, gangguan penglihatan, bahkan kematian dengan jumlah yang tidak sedikit pada saat maupun pasca terjadinya peristiwa tersebut. Dampak Psikologi yang diterima disisi lain juga memiliki efek yang cukup besar bagi korban langsung seperti trauma berkepanjangan, kehilangan orang terdekat hingga kebencian terhadap sekte keagamaan itu sendiri. Media massa dan media populer lainnya turut membangun stigma negatif bagi para penganut sekte keagamaan tersebut pasca teror dari Aum, seperti citra para pemeluk sekte agama yang dalam film-film digambarkan seperti tercuci otaknya, tidak dapat menggunakan akal sehatnya, selalu mematuhi segala perkataan pemimpin sekte meskipun tidak masuk akal. Sehingga kesan yang muncul bagi para pemeluk agama adalah orangorang yang sudah kehilangan akal.

Esai tersebut juga menjelaskan pandangan masyarakat mengenai Aum Shinrikyo sendiri maupun para pelaku teror tersebut. Salah satunya pelaku bernama Ikuo Hayashi adalah seorang dokter bedah yang menjadi elite atau petinggi di sekte religi Aum Shinrikyo. Murakami dalam Esai tersebut menjelaskan secara tersirat bahwa sebagai seorang dokter bedah Hayashi pada awalnya mengalami dilema dalam melakukan teror tersebut. Teror yang dilakukan Hayashi atas dasar mengikuti ajaran Aum yang lebih khususnya adalah perintah Asahara yaitu melakukan hal yang menghilangkan banyak nyawa bertentangan dengan kode etiknya sebagai dokter, namun disisi lain baginya hal tersebut semacam Jihad, Perang suci dalam keyakinan religi yang dianut (Murakami 2001:11). Muncul lah pertanyaan besar dibenak masyarakat 
mengapa seseorang dokter bedah yang juga bagian dari kaum Superelite dalam masyarakat Jepang seperti Hayashi rela membuang statusnya di masyarakat dan melakukan teror tersebut. Murakami dalam esainya menjelaskan bahwa hal itu dapat diasumsikan karena ia merupakan bagian dari kaum superelite atau lebih detailnya ia adalah seorang dokter yang hebat di masyarakat sehingga ia merasa ada beban di pundaknya untuk menciptakan utopianya. Telah terjadi Mistrust atau ketidak percayaan dengan sistem medis di Jepang yang sekuler sehingga ia merasa memiliki urgensi dengan menciptakan hal tersebut. Aum Shinrikyo yang dipimpin oleh Shoko Asahara dapat menjawab keresahan tersebut melalui khutbah nya yang membahas tentang metode pengobatan astral sebagai salah satu metode pengobatan dari Aum (Murakami 2001:362-362). Hal itu yang membuat Hayashi sebagai salah satu penganut Aum Shinrikyo rela melakukan hal yang bahkan bertentangan dengan kode etiknya sebagai dokter, karena hal itu dirasa merupakan hal yang harus dikorbankan untuk menciptakan utopia tersebut.

Murakami pada akhirnya menuangkan pandangannya mengenai issue tersebut melalui narasi-narasi dalam novelnya bahwa para pemeluk agama ini tidak punya pendirian, maupun logika yang sehat karena mereka cenderung mengorbankan moral untuk menciptakan utopia, menjalankan perintah agama ataupun melaksanakan perintah dari pemimpin agama yang bersangkutan. Murakami juga menyinggung bahwa para pemuka atau pemimpin agama ini bukanlah makhluk suci seperti yang digambarkan para pengikutnya dalam kutipan berikut

「でもさ、信仰深いのと性的な欲望
の強弱はまた別の問題でしょう。聖
職者にセックスマニアが多いっての
は世界の常識だよ。実際の話、売春
とか痴漢行為とかで警察にひっばら
れるやつには宗教関係者と教育関係
者がずいぶん多いんだから」

"Demo sa, shinkou bukai no to sei teki na yokubou no kyoujaku wa mata betsu no mondai deshou. Seishokusha ni sekkusu mania ga ooitte no wa sekai no joushiki dayo. Jissai no hanashi, baishun toka chikan koui toka de keisatsu ni hipparareru yatsu ni wa shuukyou kankeisha kyouiku kankeisha ga zuibun ooin dakara".

"Tapi punya keyakinan teguh terhadap religi dengan kuat lemahnya nafsu-birahi adalah permasalahan yang berbeda. Sudah menjadi rahasia umum bahwa di kalangan pendeta sendiri, ada banyak maniak seks. Kenyataannya, banyak orang dari kalangan pemeluk agama atau pendidikan ditangkap polisi gara-gara prostitusi atau pelecehan seksual.

(IQ84 J1 B23 H522)

Latar dari kutipan narasi tersebut adalah dialog Aomame dan Ayumi ketika makan malam di sebuah restoran. Perkataan tersebut diutarakan Ayumi yang kemudian di amini oleh Aomame dengan jawaban Mungkin benar begitu.

Kutipan tersebut menjelaskan pandangan yang dituangkan Murakami bahwa para pemuka agama jugalah manusia biasa, tidak perlu di kultuskan. Murakami menggambarkan nya melalui opini dari Ayumi yang mengatakan "Tapi punya keyakinan teguh terhadap religi dengan kuat lemahnya nafsu birahi adalah permasalahan yang berbeda. Sudah menjadi rahasia umum bahwa dikalangan pendeta sendiri banyak maniak seks. Kenyataannya banyak orang dari kalangan pemeluk agama atau Pendidikan ditangkap polisi gara-gara prostitusi atau pelecehan seksual (Shinkou bukai no to seiteki na yokubou no kyoujaku wa mata betsu no mondai deshou. Jissai no hanashi wa, baishun to ka chikan koui to ka de keisatsu ni hipparareru yatsu ni wa shuukyou kankeisha to kyouiku kankeisha ga zuibun ooin dakara)". Pesan yang ingin disampaikan Murakami dalam narasi tersebut adalah mengikuti ajaran agama atau arahan dari pemuka agama tetap harus mendahulukan logika dan akal sehat agar 
tidak terjebak dogma sesat maupun perbuatan yang menghilangkan nyawa orang lain yang dalam hal ini dapat diasumsikan merujuk ke teror yang dilakukan oleh Aum Shinrikyo yaitu Asahara Shoko sebagai Mastermind atau otak dari kejadian teror gas Sarin di Tokyo yang dibalut dengan doktrin Aum Shinrikyo.

\section{KESIMPULAN}

Kesimpulan dari hasil analisis yang telah di jelaskan yaitu Pandangan negatif terhadap para pemeluk agama yang digambarkan sebagai orang-orang yang berjiwa kerdil juga tidak dapat menggunakan logikanya. Hal tersebut didasari pengalaman Murakami setelah menulis karya nonfiksi nya Underground, dan juga teror yang pernah dilakukan oleh sekte agama Aum Shinrikyou yang turut mempengaruhi pandangan masyarakat Jepang terhadap sekte keagamaan.

\section{DAFTAR PUSTAKA}

Eagleton, Terry. 2006. Teori Sastra: Sebuah Pengantar Komprehensif. Yogyakarta \& Bandung: Jalasutra.
Faruk. 2012. Pengantar Sosiologi Sastra dari strukturalisme genetik sampai postmodernisme. Yogyakarta: Pustaka Pelajar.

Moleong, Lexy J. 2015. Metode Penelitian Kualitatif. Bandung: PT Remaja Rosdakarya.

Murakami, Haruki. 2001. Underground. New York: Vintage International.

Murakami, Haruki. 2010. 1Q84 (ichi-kewhachi-yon). Tokyo. Shinchosa Publicing Co. Ltd.

Ratna, Nyoman Kutha. 2007. Sastra dan Cultural Studies Representasi fiksi dan Fakta. Yogyakarta: Pustaka Pelajar.

Ratna, Nyoman Kutha. 2016. Teori, Metode dan Teknik Penelitian Sastra dari Strukturalisme Hingga Postrukturalisme Perspektif Wacana naratif. Yogyakarta: Penerbit Pustaka Pelajar.

Wellek, R. dan Austin Warren. 1949. Theory of Literature. New York: Harcourt Brace and Company. 